\title{
Ukrainian-Chinese collaboration: Prospects of development
}

\author{
Oleh $\mathrm{Kratt}^{1 *}$, Kateryna Pryakhina ${ }^{2}$, and Maryna Bilyk ${ }^{3}$ \\ ${ }^{1}$ Doctor of Economics, professor, Kremenchuk Mykhailo Ostrohradskyi National University, Ukraine \\ ${ }^{2} \mathrm{PhD}$ candidate, Kremenchuk Mykhailo Ostrohradskyi National University, Ukraine \\ ${ }^{3} \mathrm{PhD}$ student, Kremenchuk Mykhailo Ostrohradskyi National University, Ukraine
}

\begin{abstract}
In article the current state of the Chinese-Ukrainian relations is analysed, the priority directions of strategic cooperation are considered. The analysis of economic development of Ukraine and China with definition of positive and negative tendencies is carried out. It is certain that there is a mutual aspiration of the parties before increase in volumes of bilateral trade, diversification of its structure, development of long-term forms of economic cooperation, deepening of investment interaction between Ukraine and China. The analysis of the study is conducted during 2010-2016 years. We have identified prospective investment sectors within the framework of cooperation between Ukraine and China - Transport Infrastructure, Agriculture, Renewable energy, Telecommunications, IT, educational sphere. The current dynamics of the trade balance between Ukraine and the People's Republic of China, taking into account the considerable predominance of imports, requires a thorough review of trade policy measures: to improve the structure of trade, introducing new forms of trade relations, To develop the institutional framework for cooperation, To search for ways to reduce the energy intensity of export industries, To stimulate the means of tariff and non-tariff regulation of imports into Ukraine of mainly investment high-tech goods. The forecast of possible risks according to each perspective direction of development is made.
\end{abstract}

Key words: collaboration, development, analysis, economic relations, prospects

\section{Introduction}

For this time People's Republic of China is one of the world economic leaders whose value in high gear grows in many spheres of the international life. The certificate of it is election of national monetary unit of China - yuan - world reserve currency on the basis of which the cost of special drawing right of the IMF is calculated. Ukraine, in turn, has rather high economic potential, world achievements in some fields of science and technology, an advantageous geopolitical position which does it by a zone of certain economic and political interests, in particular for People's Republic of China. The mutual understanding of these realities also became the main prerequisite of formation and development of the Ukrainian-Chinese relations. The analysis of the study is conducted during 2010-

\footnotetext{
${ }^{*}$ Corresponding author: katerinapryakhina@gmail.com
} 
2016 years, import and export indicators and the balance of foreign trade balance used. The forecast of possible risks according to each perspective direction of development is made.

The purpose of article is the research of character and the prospects of development of the modern Ukrainian-Chinese economic relations.

\section{Data and Methods}

The scientific article uses general scientific methods: statistical analysis for studying, grouping, comparison of indices of total turnover of countries, graphic method - for visual representation of tables and schemes. Promising directions for the development of relations between China and Ukraine are analyzed and the risk forecast for investors is synthesized.

\section{Results}

To date, a significant number of Ukrainian scholars view the Chinese vector of Ukraine's foreign policy as one of the highest priority. Works by Pron [1] devoted to the history of the formation and development of Ukrainian-Chinese relations. The author believes that countries have deep and strong historical traditions that cover multidectoral spheres of politics, economics, and culture. Among the latest publications, it is worth highlighting articles by Holod [2], which explores China's investment expansion in terms of prospects for developing relations with Ukraine. Vysotskaya [3] in her studies carried out a thorough analysis of the main trends and prospects for the development of Ukrainian-Chinese economic relations. In the scientific work of Rogovuy [4] discusses the prospects and risks of developing Ukrainian-Chinese trade and economic relations. Ukrainian-Chinese economic cooperation in the context of foreign economic security it took place in scientific works by Levkivskyi [5]. The mechanism of international economic relations between the two countries is considered and the priority promising areas for further development of foreign economic relations between China and Ukraine are singled out. Grodsky [6] researches modern trade and investment cooperation between Ukraine and China. The strategic guidelines for intensify cooperation between Ukraine and China in the context of globalization are outlined. On the special role of bilateral cooperation to strengthen economic presence of Ukraine in the Asian region is focused [6]. Position of Ukraine in the PRC's system of foreign economic relations it took place to be in scientific works by Vlasenko L. In the article foundations of Chinese theory of international relations have been considered, differences between Chinese and classical Western concepts of international interactions were highlighted. Existing hierarchy of PRC's strategic partnership was analyzed [7]. In scientific work from Cheng [8], the choice and strategic opportunities of China in the context of «Ukrainian crisis» was analyzed the determining factors that influenced the choice of China in the context of «Ukrainian Crisis», taking into account the geo-economic and geo-political interests of China. It is also proved that contrary to the European Union and the United States of America, who often use political tools to resolve conflicts (which often leads to disputes and conflicts escalation), China offers economic settlement mechanisms that are acceptable to all stakeholders. Halperina [9] is studying a question about System adaptation of social and economic model of China to conditions of global instability. The features of the system adapt social and economic model of China to the conditions of global instability. Thesis determined new conditions of socio-economic model of China.

In the years of Ukraine's independence, these relations have generally followed an upward trend and reached a peak in December 2013 when the Treaty of Friendship and 
Cooperation was signed.China's interest in cooperation with Ukraine is also linked to the decision of the Chinese leadership to create "foreign food bases". In particular, it includes the use of Ukraine's agricultural opportunities combined with China's investment and technological capacities. The current Ukraine-China relations are largely influenced by China's growing political and economic interests regarding the countries of the EU and New Eastern Europe (Belarus, Ukraine, Moldova, Latvia, Lithuania, and Estonia). China plans to implement its global strategy to increase exports and investment in potential markets located between Russia and the EU. Ukraine could become an important place to promote Chinese products and brands, gain access to new markets, and acquire strategic assets. Despite China's interest towards Ukraine, these relations were put on hold since the beginning of the Revolution of Dignity. Likely, this is because rapprochement with Ukraine can go only as far as China will be able to maintain its safe balance in the geopolitical USRussia-China triangle and in the world [10].

It costs to mark, that world economic relations represent a combination of different forms of business interaction that occurs between countries of the world, and primarily include trade and economic cooperation, the flow of investment flows, scientific and technical ties, the exchange of technologies and intellectual property.

Therefore, it is advisable to look more closely at each of the forms of interaction between Ukraine and the People's Republic of China at the present time.

According to the General Customs Administration of the People's Republic of China, in 2016, the trade turnover between Ukraine and the PRC amounted to \$ 6520.2 million. At the same time, Chinese exports to Ukraine - 4687.7 million. The US (increase by $32.2 \%$ ), Chinese imports from Ukraine amounted to $\$ 1,832.5$ million (decrease by $24.1 \%$ ). Balance of bilateral trade in favor of PRC amounted to $\$ 2855.2$ million [11]. The average growth rate $\bar{R}$ was used to substantiate the evaluation of the change in indicators.

Table 1. Dynamics of foreign trade turnover of Ukraine with China for 2010-2016, million USD

\begin{tabular}{|c|c|c|c|c|c|c|c|c|}
\hline Year & 2010 & 2011 & 2012 & 2013 & 2014 & 2015 & 2016 & $\begin{array}{c}\bar{R}, \\
\%\end{array}$ \\
\hline Export & 1316,6 & 2180 & 1777,2 & 2726,7 & 2674,1 & 2399,1 & 1832,5 & 5,6 \\
\hline Imports & 4700,4 & 6268,3 & 7899,6 & 7903,2 & 5411,0 & 3771,0 & 4687,7 & -1 \\
\hline Balance & $-3383,8$ & $-4088,3$ & $-6122,4$ & $-5176,6$ & $-2736,8$ & $-1371,9$ & $-2855,2$ & -3 \\
\hline $\begin{array}{c}\text { Total } \\
\text { turnover }\end{array}$ & 6017 & 8448,3 & 9676,8 & 10629,9 & 8085,1 & 6170,1 & 6520,2 & 1 \\
\hline
\end{tabular}

The indicators of Table 1 show that the average growth rate of export is $5.6 \%$, which indicates an increase in exports every year by $5.6 \%$. In this case, the import rate decreases by $1 \%$ and Balance in $3 \%$. The total turnover is increased every year by $1 \%$. The highest indicator of Ukrainian export operations is for 2013 (\$ 2726.7 million, Fig. 1). For the period from 2014 to 2016 there is a significant reduction in the volumes of exported goods, which is explained by the political situation in the south and east of Ukraine, under the influence of Russian aggression. This also applies to imported Chinese goods to Ukraine (a significant reduction in 2015 to $\$ 3771$ million). The presence of a negative balance in bilateral trade with China puts Ukraine ahead of the task of finding ways to increase the volume of Ukrainian exports. 


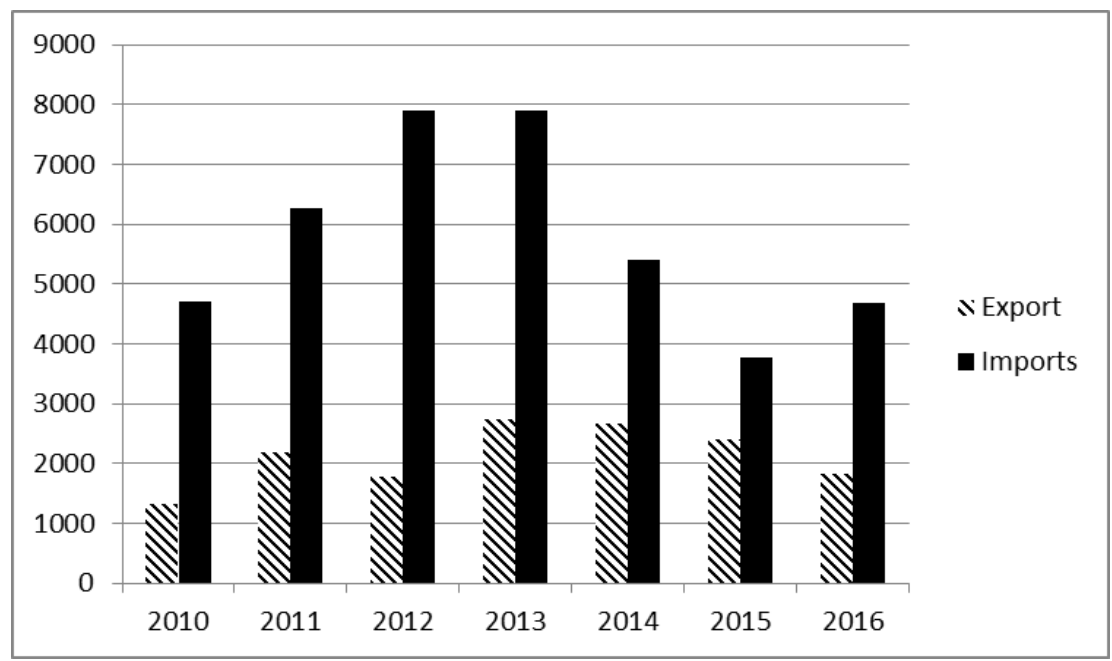

Fig. 1. Indicators of export-import operations of Ukraine with China for the period 2010-2016

Most specific gravity in the structure of export for today is occupied by supplying with mineral products, grain-crops, fats and oils of animal or vegetable origin. It is possible to mark, that the Ukrainian export to Republic of China has raw material character mostly. The main reason for this is to orient the Chinese market to self-sustaining and stimulate the domestic producer, correspondingly reducing the number of industries in which, given the lack of Chinese counterparts, significant imports would be available (Fig. 2).

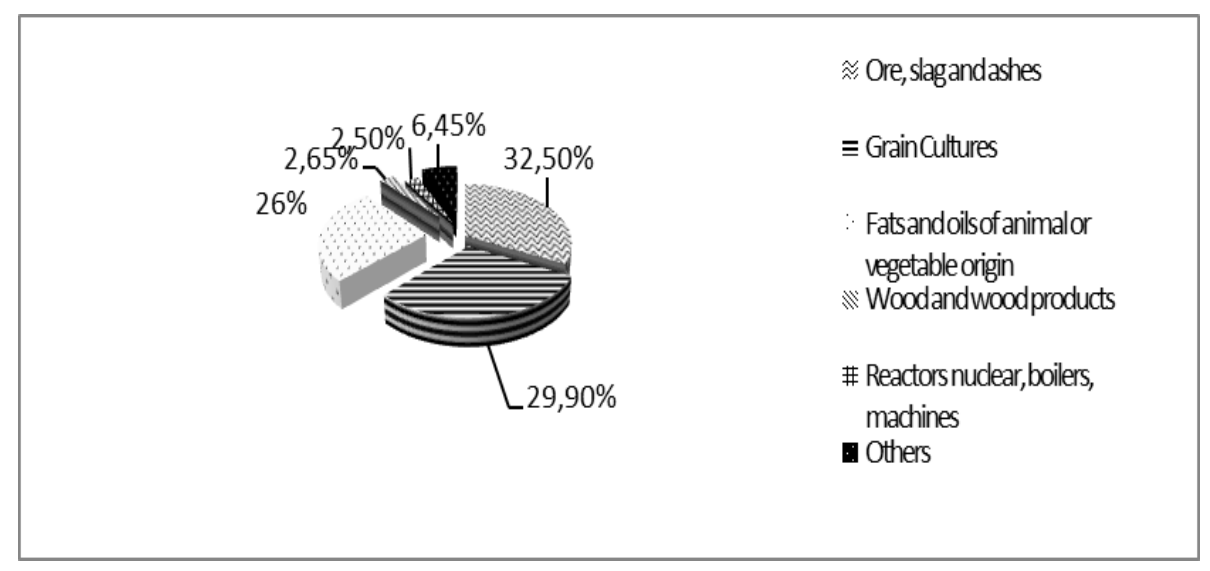

Fig. 2. Indicators of exports of Ukrainian products to China in 2016

The basis for imports from China in 2016 was: electric machines - 22.5\%; nuclear reactors, boilers and machines - 17,1\%; plastics, polymeric materials $-6.1 \%$; ferrous metals $-4.4 \%$; organic chemical compounds $-3.7 \%$; various chemical products $-3.7 \%$; footwear $-3.5 \%$; articles of ferrous metals $-3 \%$ [12].

Summarizing the above-mentioned, it is possible to state that the export-import operations and development cooperation directions of the last years have shown that the increase in commodity turnover will occur due to increase in import to the Ukraine of Chinese products and services. Thus the volumes of home export in PRC have saltatory 
character (Fig. 1) and hardly will exceed a monthly index in the 250 million дол USA in a prospect.

In 2015 Ukraine joined initiative "One belt, signing one way" from PRC "Protocol about a collaboration within the framework of the Silk way", and now, actually, the searches of deepening and activations of trade and economic relation are conducted between countries within the framework of this protocol.

A bilateral investment collaboration does not answer possibilities of China and necessities of Ukraine as yet. The increase of volumes of import from PRC in 2016 is not accompanied by activation of investment collaboration $(0,48 \%$ in the general volume of the attracted lines of foreign investments), the Ukrainian investments in PRC are practically absent also [11].

Priority for development of mutually beneficial investment collaboration are such spheres, as transport, agricultural, creation of infrastructural objects, space, innovative, aviation, scientific, technical and other spheres.

Basic investment projects are within the framework of collaboration between Ukraine and China.

1. Mechanical engineering. The Beijing Skyrizon Aviation Industry Investment Co Ltd company created with Ukrainian "Motor Sich" joint venture which is based already in China. Construction of a factory for the production and maintenance of aircraft engines was started in Chongqing City. At the AirshowChina 2016 exhibition the Beijing Skyrizon company declared a possibility of license production by joint venture of the D-136 helicopter engines, MC-500B and TV3-117VMA-SBM1V and engines for planes of general purpose A-450C, turbojet D436-148FM and D-18T, etc. Beijing Skyrizon finances production start, and the Ukrainian side provides technologiesA certain risk for our state is the lack of the strategic directions from use and loan of the Chinese technologies and innovations that could become a push to improvement of the technologies which are available in Ukraine and attraction of foreign experience.

2. Renewable energy. The CNBM International Corporation in Ukraine owns the 10 largest solar power plants located in the Mykolayiv and Odessa regions. Their capacity is 267 MW, while the power of all Ukrainian solar power plants reaches $500 \mathrm{MW}$. According to CNBM, the investment amounted to about $\$ 1$ billion.

3. Agro-industrial complex The Chinese corporation COFCO Agri launched in 2016 in the Mykolaiv Sea Commercial Port a transshipment complex of grain and oilseeds with an annual capacity of 2.5 million tons. The investment project cost $\$ 75$ million, it is already working properly, and from the Ukrainian water area there are steamships with grain for the People's Republic of China. Several elevators and an oil extraction plant are also controlled by COFCO Agri in Ukraine.

Beginning in 2013 around the village of Naumovka, located in the Chernihiv region in the north of Ukraine is a farm company, which is founded by the large Chinese Agricultural State Corporation Huangfantsyu. Today, In Venture Investment Group is leading a major player in the soybean market and soybean oil production in China, which is interested in purchasing or building refineries in Ukraine.

4. Sphere of telecommunications. The office of the Chinese company Xinwei Group, one of the leading telecommunication companies in the world, is opened in Kyiv in 2014. The Ukrainian telecommunications operator Prostate builds a 4-generation mobile broadband multimedia communications network based on the McWiLL technology of the Xinwei Group. 150 base stations have already been installed, which covered Kyiv and significant territory from Kharkiv to Mariupol, and the "strip" coverage runs through 4 eastern regions of Ukraine. Further informatization is an important tool for the development of all social spheres of Ukraine. It is in the common interest of Ukraine and China to continue to work on this issue [13]. 
A number of investment projects which the Chinese investors in Ukraine intend to realize is perspective. From the last: waste recycling plant in the Lviv region, processing of waste in Ukraine, thermal power plant in the Zhytomyr region, the belt road near Kiev, the bridge in Kremenchuk, the airport in Zhytomyr and other infrastructure facilities.

Ukraine and China actively develop cooperation in the cultural and humanitarian sphere. The development of cooperation between Ukrainian universities, educational and scientific organizations of the Republic of China has positive dynamics and significant prospects for further growth. One of the priority areas of cooperation is the training of Chinese citizens in Ukrainian higher education institutions. The practice of creating joint institutes will test new teaching methods. Preparation and conducting internships for students, graduate students and young scientists is one of the priority areas of bilateral cooperation.

It should also be noted the intensification of the Ukrainian-Chinese dialogue at the expert level. The Ukrainian and Chinese experts often meet, communicate and exchange opinions at different conferences, meetings, forums A significant amount of expert meetings shows the mutual aspiration to find the solution for the existing problems. Expert discussions help to find compromises, to overcome differences, to strengthen bilateral dialogue and to develop a further strategy for the development of relations. We hope that current expert work will be implemented at the political and economic level in concrete intergovernmental agreements. Therefore, in our opinion, directions of cooperation between Ukraine and China in the following areas are promising (Table 2). 
Table 2. Directions of cooperation between Ukraine and China

\begin{tabular}{|c|c|c|}
\hline $\begin{array}{c}\text { Sphere of } \\
\text { cooperation }\end{array}$ & Development prospects & Risk forecast to investors \\
\hline $\begin{array}{c}\text { Transport } \\
\text { Infrastructure }\end{array}$ & $\begin{array}{l}\text { - development of a network of multimodal } \\
\text { transport corridors using water (maritime) } \\
\text { and rail links in the North-South and West- } \\
\text { East directions. (One of the promising } \\
\text { projects in the context of the development } \\
\text { of trade routes is a deep sea port project that } \\
\text { could actually double the capacity of the } \\
\text { Ukrainian port infrastructure for the needs } \\
\text { of the New Silk Road) }\end{array}$ & $\begin{array}{l}\text { - legislation of Ukraine is imperfect } \\
\text { in the field of customs, tax, } \\
\text { investment regulation, } \\
\text { - the renewal of the fleet of rolling } \\
\text { stock of Ukrainian carriers is slow, } \\
\text { - there is a low activity in the } \\
\text { implementation of projects in } \\
\text { Ukraine for the construction of } \\
\text { high-speed roads (railways, motor- } \\
\text { car), including paid, introduction } \\
\text { and development of multimodal } \\
\text { transport and logistics. }\end{array}$ \\
\hline Agriculture & $\begin{array}{l}\text { - export of meat and dairy products, seeds } \\
\text { of oilseeds and nuts, } \\
\text { - cooperation in the development of } \\
\text { infrastructure and logistics, more active and } \\
\text { close cooperation in the field of veterinary } \\
\text { and phytosanitary, } \\
\text { - cooperation in the field of geodatabase } \\
\text { and geospatial data generation, } \\
\text { - development of smart farming, } \\
\text { - the construction of plants on the } \\
\text { production of means of plant and fertilizer } \\
\text { protection on the territory of Ukraine, the } \\
\text { use of new technologies for raising the } \\
\text { productivity and productivity of cattle } \\
\text { breeding and poultry farming. }\end{array}$ & $\begin{array}{l}\text { - the technical condition of } \\
\text { agricultural enterprises does not } \\
\text { meet the needs of production, } \\
\text { - monopolization of the corporate } \\
\text { agro-sector of the markets of } \\
\text { resources, especially financial, } \\
\text { channels of product sales, } \\
\text { - restriction of the circulation of } \\
\text { agricultural land. }\end{array}$ \\
\hline $\begin{array}{l}\text { Renewable } \\
\text { energy }\end{array}$ & $\begin{array}{l}\text { - energy efficiency and rational use of } \\
\text { nature: (the branch of alternative energy - } \\
\text { solar, river, wind, etc.). }\end{array}$ & $\begin{array}{l}\text { the risks of changing the } \\
\text { legislative framework for a green } \\
\text { tariff and the lack of an updated } \\
\text { strategy for renewable energy in } \\
\text { Ukraine by } 2035 \text {, } \\
\text { - the complexity of the tax system. }\end{array}$ \\
\hline $\begin{array}{l}\text { Telecommu- } \\
\text { nications, } \\
\text { IT }\end{array}$ & $\begin{array}{l}\text { - new prospects opens for Ukraine a project } \\
\text { for the creation of a new all-Ukrainian } 4 \mathrm{G} \\
\text { network with the help of the Chinese side, } \\
\text { - cooperation in the field of information } \\
\text { technologies on the basis of Ukrainian IT } \\
\text { Start-Up. }\end{array}$ & $\begin{array}{l}\text { - the existence of legal and } \\
\text { organizational barriers, } \\
\text { - the complexity of the tax system, } \\
\text { bureaucracy insufficient reliability } \\
\text { of information infrastructure. }\end{array}$ \\
\hline $\begin{array}{c}\text { Educational } \\
\text { sphere }\end{array}$ & $\begin{array}{l}\text { - signing an agreement on the mutual } \\
\text { increase of student quotas for exchange, } \\
\text { - concluding agreements on cooperation } \\
\text { and implementation of the China-Ukrainian } \\
\text { double diploma program, } \\
\text { - preparation and internship of graduate } \\
\text { students and young scientists on the basis of } \\
\text { mutual exchange, } \\
\text { - conducting international educational } \\
\text { forums, including The Forum of Rectors of } \\
\text { Ukrainian and Chinese Universities, in } \\
\text { order to expand the direct cooperation of } \\
\text { universities. }\end{array}$ & $\begin{array}{l}\text { - language barriers - deepening } \\
\text { mutual learning of Chinese and } \\
\text { Ukrainian languages, } \\
\text { - the beginning of reforms in the } \\
\text { educational sphere. }\end{array}$ \\
\hline
\end{tabular}




\section{Discussion and Conclusion}

Considering the conducted research it is possible to draw the following conclusions.

Firstly, Ukraine has an important geopolitical and geo-economic situation, making it an important transport and logistics hub within the framework of the Silk Road Infrastructure Project, which aims to connect Europe and Asia more closely. The Silk Road initiative gives Ukraine the technical ability to bypass the restrictions imposed by Russia on the transit of its products to the countries of Central AsiaMoreover, our country is interesting to China as a production site for further export to the EU. This aspect has a positive impact on the development of Ukrainian-Chinese economic relations.

Secondly, China is one However, the trade balance for Ukraine is negative. Imports of goods from China to Ukraine in 2016, according to state statistics, grew by $24.3 \%$ (to $\$ 4687.7$ million), exports decreased by $24.1 \%$ compared to 2015 (before $\$ 1832.5$ million). However there is a mutual aspiration of the parties before increase in volumes of bilateral trade, diversification of its structure, development of long-term forms of economic cooperation, deepening of investment interaction between Ukraine and China. The deepening of trade relations with the PRC positively affects Ukraine's economic growth, however, the current dynamics of the trade balance between Ukraine and the PRC, given the significant predominance of imports, requires careful review of trade policy measures. Therefore, our proposals are as follows:

1. To improve the structure of trade, introducing new forms of trade relations, in particular industrial cooperation, cooperation on a compensation basis and the organization of joint productions through the purchase of licenses.

2. To search for ways to reduce the energy intensity of export industries as it significantly affects the competitiveness of Ukrainian exports.

3. To develop the institutional framework for cooperation, which should include not only interstate macroeconomic, but also a number of sectoral bodies for establishing effective cooperation in specific areas.

4. To stimulate the means of tariff and non-tariff regulation of imports into Ukraine of mainly investment high-tech goods.

5. Creation of a common investment fund on parity terms.

Thirdly, China is interested to invest the investments in economy of Ukraine, considering its branched transport system, existence of a powerful scientific and industrial complex, access to the markets of the European Union. It is confirmed by a number of already realized investment projects (the creation of Beijing Skyrizon Aviation Industry Investment Co Ltd and Motor Sich joint venture, tart in 2016 in the Nikolaev sea trade port transshipment facility of grain and oil-bearing crops, etc). And today the complementary nature of economic systems, the presence of a significant potential for cooperation in the trade, economic, scientific and technical, and humanitarian sectors create the necessary prerequisites for the progressive development of mutually beneficial Ukrainian-Chinese relations.

\section{References}

1. S. Pron, China: Foreign Policy and Diplomacy in the Second Half of the 20th Century. Monograph Nikolaev, 147, (2012)

2. V. Holod, China Investment Expansion. Prospects for Developing Relations with Ukraine, Chinese research studies, 38-44 (2012)

3. M. Vysotskaya, Analysis of the main trends of development between Ukraine and China Strategy of development of Ukraine. Economics, sociology, law, 13-18 (2013) 
4. V. Rogovuy, Prospects and risks of Ukrainian-Chinese trade and economic relations development. Bulletin of Zhytomyr State Technological University, 68 (2016)

5. V. Levkivskyi. Ukrainian-Chinese economic cooperation in the context of foreign economic security. Scientific herald of the Chernihiv State Institute of Economics and Management, Series 1: Economics, 95-103 (2013)

6. S. Grodsky, Modern trade and investment cooperation between Ukraine and China, Economic analysis, 202-206 (2013)

7. L. Vlasenko, Position of Ukraine in the PRC's system of foreign economic relations. Scientific herald of Uzhgorod National University. Series: International Economic Relations and World Economy, 15-19 (2017).

8. H. Cheng, The choice and strategic opportunities of China in the context of Ukrainian crisis. Foreign Trade: Economics, Finance, Law, 117-128 (2015).

9. L. Halperina, System adaptation of social and economic model of China to conditions of global instability. [online], Available at: http://ir.kneu.edu.ua/ (2016)

10. Euromaidan Press [online], Available at: http://euromaidanpress.com/ (2017)

11. Embassy of Ukraine in the People's Republic of China and Mongolia (in combination) [online], Available at: http://china.mfa.gov.ua/ua/ukraine-cn/trade (2017)

12. Official site of the State Statistics Service of Ukraine [online], Available at: http://www.ukrstat.gov.ua (2017)

13. Silk Road of Ukraine [online], Available at: http://silkroad.in.ua/ (2017) 
